\title{
Central European History and the Holy Roman Empire
}

\author{
Joachim Whaley
}

Central European History began to appear at a crucial juncture in the historiography of the Holy Roman Empire. Of course its remit was much broader. Founded sixteen years before the British journal German History, Central European History, together with the Austrian History Yearbook (founded 1965) and the East European Quarterly (founded 1967), took over the role occupied between 1941 and 1964 by the Journal of Central European Affairs. Each of these US journals shared an openness to new approaches and to work on all periods since the Middle Ages as well as a desire to keep 'readers abreast of new literature in the field...' with 'reflective, critical reviews or review articles dealing with works of central importance... [and] bibliographical articles dealing with limited periods or themes...'

This was an ambitious programme but, remarkably, the journal was as good as its word in relation to medieval and early modern studies. ${ }^{2}$ The second issue in Volume 1 (1968) published William J. McGill on Kaunitz's Italian policy; Volume 2 brought Theodor Brodek on 'Lay Community and Church Institutions of the Lahngau in the Late Middle Ages' and Mack Walker on 'Napoleonic Germany and the Hometown Communities'. Successive volumes included important essays by Leon Stein, Otakar Odložilík, Carl C. Christensen, Marlene Jahss LeGates, James Allen Vann, Bodo Nischan, Stephen W. Rowan, Thomas J. Glas-Hochstettler, R.J.W. Evans and others. The first major review articles on pre-modern subjects appeared in 1978 with Erik Midelfort's fine survey 'The Revolution of 1525? Recent Studies of the Peasants' War' and Gerald Strauss's essay 'The Holy Roman Empire Revisited'.

It is difficult now to imagine how important this was for English-language scholarship on early modern German-speaking Europe. In the 1960s, as work on virtually every period in German history after 1800 flourished in the English-speaking world, almost no attention was paid to the Holy Roman Empire. As Tim Blanning recently recalled, when he became interested in German history before 1800 as a student at Cambridge in the 1960s there was no significant body of English-language research on the subject and little interest creating one. ${ }^{3}$ That was true particularly of the early modern period but medieval German history fared little better.

The comments to be found in the most popular surveys of German history, AJP Taylor's The Course of German History and Geoffrey Barraclough's The Origins of Modern Germany, were not encouraging. ${ }^{4}$ Hajo Holborn's survey volumes on the Reformation era and the period from 1648 to 1840, the first two volumes of his three-volume History of Modern

\footnotetext{
1 'From the Editors', Central European History, i (1968), p. 3.

${ }^{2}$ The following information is taken from a search of the JSTOR index for Central European History.

${ }^{3}$ T.C.W. Blanning, 'The Holy Roman Empire of the German Nation past and present', Historical Research, 85 (2012), pp. 57-70.

${ }^{4}$ A. J. P. Taylor, The Course of German History: a Survey of the Development of German History since 1815 (1945); G. Barraclough, The Origins of Modern Germany (Oxford, 1947).
} 
Germany, appeared in 1959 and 1964. Frederick Hertz published his first two volumes on The Development of the German Public Mind, covering the period from the Middle Ages to the Enlightenment in 1957 and 1962. Both works had their merits yet both were marked by their authors' experience of persecution and exile during the Third Reich. In many ways each perpetuated a familiar narrative of backwardness and an inexorable journey towards disaster in the twentieth century. These had a long pedigree.

Almost everyone who has worked on the empire is wearily familiar with Voltaire's sardonic quip that it was 'Neither holy, nor Roman, nor an empire'. Quite frequently this is the only thing that non-historians, and many historians of modern Germany, 'know' about the Holy Roman Empire. Yet the statement is in fact invariably misquoted. These words in Voltaire's essay on the customs and spirit of nations published in 1756 referred specifically to the empire at the end of the reign of Charles IV. Voltaire meant simply that once it had largely shed its concern with Italy and the papacy its title was no longer accurate. On the whole, his view of the empire as a German polity was rather positive; and his view was similar to that of many French writers of the eighteenth century who rather admired the German empire as a kind of republic or limited monarchy. ${ }^{5}$

Yet Voltaire's characterisation of the empire later became popular because it could be cited, albeit wrongly, in support of the negative views that prevailed for much of the nineteenth and twentieth centuries. Many nineteenth-century and early twentieth-century German and Austrian historians despised it for not being a nation state and blamed it for delaying the development of the Germans. They often praised the territories for their cultural achievements but refused to recognise the ways in which the empire made them possible. Critics of Germany before and after 1945 often sought to establish the continuity from first Reich to Third Reich, which cast sombre shadows over the centuries before $1806 .{ }^{6}$

The views of scholars working outside Germany generally reflected those of their Germanspeaking colleagues, though the tone was often influenced by concerns about the growing power of the new Germany after 1871 or, later, by Nazism and the Third Reich and the aftermath of the Holocaust and the Second World War. Even the fundamentally pro-German James Bryce was negative. He was interested in the potential of the empire for the exercise of supranational authority. His history of the empire, first published in 1864 and still in print today, made it clear, however, that it failed in this mission. ${ }^{7}$

From around 1500 at the latest, Bryce argued, the empire had simply become a German kingdom. This created the framework for a remarkable diversity of culture, but the empire's international mission was gone. In Germany itself, the Reformation brought bitter internal divisions and 'while the princes became shamelessly selfish, justifying their resistance to the

\footnotetext{
${ }^{5}$ Voltaire, Essai sur les moeurs et l'esprit des nations, ed. Bruno Bernard et al., Les oeuvres completes de Voltaire vol. 24 (Oxford, 2011), p. 41. See also Guido Braun, La connaissance du Saint-Empire en France 1643-1756 (Munich, 2010), pp. 584-7.

${ }^{6}$ There is a good overview of the historiography in Matthias Schnettger (ed.), Imperium Romanum - Irregulare corpus - Teutscher Reichs-Staat. Das Alte Reich im Verständnis der Zeitgenossen und der Historiographie (Mainz, 2003).

${ }^{7}$ John T. Seaman, Jr., A Citizen of the World. The Life of James Bryce (London, 2006), pp. 41-4, 128-30.
} 
throne as the defence of their own liberty - liberty to oppress the subject — and ready on the least occasion to throw themselves into the arms of France, the body of the people were deprived of all political training, and have found the lack of such experience impede their efforts to our own time' ${ }^{8}$ The Germans, he concluded, now live 'submissive to paternal government, and given to the quiet enjoyments of art, music, and meditation, they delight themselves with memories of the time when their conquering chivalry was the terror of the Gaul and the Slav, the Lombard and the Saracen'. 9

Others were less charitable. The US literary and cultural historian Edwin Hermann Zeydel wrote in 1918 that the empire 'had no history at all' after 1648 and that 'it continued for a while longer to lead a miserable, meaningless existence because its patient, slow-moving subjects lacked the initiative and in many cases the intelligence to effect its actual dissolution'. ${ }^{10}$

After 1914-18 developments in Germany prompted much more urgent and more negative views. In France Edmond Vermeil warned the French public of the danger posed by Hitler and Nazism and placed contemporary events in historical perspective in his Germany's Three Reichs: Their History and Culture. ${ }^{11}$ In the US, William Montgomery McGovern's From Luther to Hitler: The History of Fascist-Nazi Political Philosophy undertook a similar task. ${ }^{12}$ In the UK the most successful work of this kind was AJP Taylor's The Course of German History of 1945, which argued that the whole of German history predisposed the Germans to Nazism and that Hitler fulfilled the imperialist fantasies that had gripped the Germans since the days of Charlemagne. ${ }^{13}$

After 1945 historians continued to work with an interpretative framework which was unfavourable to the development of significant popular interest in the empire. Until the 1980s the most widely read history of Germany was Johannes Haller's Epochen der deutschen Geschichte. ${ }^{14}$ First published in 1923, Haller frequently adapted, updated and amended his text until his death in 1947; others took on that task thereafter and perpetuated Haller's narrative of decline from promising early medieval foundations.

Alongside this evergreen 'classic' and others like it, historians of modern Germany developed the Sonderweg myth which cast shadows over the whole of German history This was the negative counterpoint to the positive 'besonderer deutscher Weg' that so many German historians extolled before $1945 .{ }^{15}$ In both the positive and the new negative view, the

\footnotetext{
${ }^{8}$ James Bryce, The Holy Roman Empire, $6^{\text {th }}$ edn (London, 1922), p. 425.

${ }^{9}$ Ibid.

${ }^{10}$ Edwin Hermann Zeydel, The Holy Roman Empire in German Literature (New York, 1918, republished 1966 and 2009), p. 15.

${ }^{11}$ Edmond Vermeil, Germany's Three Reichs: Their History and Culture (London, 1944).

${ }^{12}$ William Montgomery McGovern, From Luther to Hitler: the History of Fascist-Nazi Political Philosophy (New York, 1941).

${ }^{13}$ A.J.P. Taylor, The Course of German History: A Survey of the Development of Germany since 1815 (London, 1945), pp. 13-33.

${ }^{14}$ Benjamin Hasselhorn, Johannes Haller: Eine politische Gelehrtenbiographie: mit einer Edition des unveröffentlichten Teils der Lebenserinnerungen Johannes Hallers (Göttingen, 2015), pp. 166-82.

${ }^{15}$ Bernd Faulenbach, Ideologie des deutschen Weges: die deutsche Geschichte in der Historiographie zwischen Kaiserreich und Nationalsozialismus (Munich, 1980); Dieter Langewiesche, 'Der "deutsche Sonderweg".
} 
empire served simply as a rather dismal backdrop to the developments of the nineteenth and first half of the twentieth century. It was an entity that had failed to become a state. Its medieval period ended in chaos in the thirteenth century. Its early modern period was characterised by religious division, fragmentation, civil war and foreign domination. Nothing in its thousand-year history, it was held, had prepared the Germans for the modern world. Precisely because the Germans had no long pre-history of nationhood, statehood, or democratic struggle, so the argument generally continued, they plunged themselves willingly into the disasters of German nationhood and statehood that unfolded after 1871 ..

At the same time, however, new approaches to the history of the empire now also gradually developed which ultimately resulted in the positive views that are prevalent today. Perhaps inevitably the empire's sheer longevity impeded the emergence of any overall view. Research activity was organised either around chairs of medieval history or around chairs of early modern history. For a long time there was little dialogue between the two areas of study. It was only in the 1970s that scholars such as Peter Moraw began to illuminate the transition from the late Middle Ages to the early modern period, though the initial result of that was simply that the later medieval period became 'reassigned' to the early modern period. Only recently have scholars who advocate a new 'cultural' approach to the Holy Roman Empire engaged more seriously with ideas originally developed by medieval historians.

In East Germany the materialist conception of history initially focussed scholarship on the 'two paths theory' that traced the interaction between a progressive path and a reactionary path in German history. The triumph of the 'anti-national class of the German territorial princes', the establishment of the repressive absolutist state and the emergence of Brandenburg-Prussia characterised the reactionary path in the early modern period. The progressive path comprised the 'early bourgeois revolution' and the failed revolutionary mass movement of 1525. In the 1970s a more inclusive approach developed as the two paths were redefined as 'heritage' (reactionary) and 'tradition' (progressive), both being essential to the development of German society. Overall, however, the triumph of reactionary forces over the popular mass movement in 1525 was still presented as the point after which Germany was cast into darkness and the revolutionary impetus passed to the Netherlands and England.

Work on the Holy Roman Empire in western Germany after 1945 was shaped, firstly by the realisation that the old national historiography had no future and, secondly, the interest of Catholic historians a corporatist and federal alternative to the Prussian-German nation state. Traditions of diversity, peaceful integration and commitment to a higher moral law were preferable to the nightmare of Prussian militarism. The empire was attractive precisely because it was not a nation state but something supranational and European.

The real post-1945 pioneers in historical scholarship on the early modern Holy Roman Empire also tended to be Catholics, from the Rhineland, Bavaria or Austria; the names of Konrad Repgen, Heinrich Lutz and Karl Otmar von Aretin spring to mind most readily. The

Defizitgeschichte als als geschichtspolitische Zukunftskonstruktion nach dem Ersten und Zweiten Weltkrieg', in idem, Zeitwende: Geschichtsdenken heute, ed. Ute Planert and Nikolaus Buschmann (Göttingen, 2008), pp. $164-71$. 
outcome of their work on Charles V (Lutz), the Thirty Years' War and the Peace of Westphalia (Repgen) and the empire in the eighteenth century (von Aretin) was to foster a much more positive view of the empire. ${ }^{16}$ While still convinced that its demise was inevitable, they showed that the empire functioned well and endured far longer than any subsequent German polity.

These scholars rejected the idea that the empire's early modern history was a protracted period of steady decline punctuated by spectacular episodes of failure. But they view the centuries before that as a period characterised by constitutional innovation and by the development of the empire into a Rechts-, Verteidigungs-, und Friedensordnung by 1648. The empire's very existence guaranteed the peace and stability of Europe as a whole. It could not itself wage unprovoked war on any external power or territory. One of its main functions was to organise the collective defence of its members against foreign attack. It also devised mechanisms which served to defend the existence and rights of all of its members against domestic aggression and to maintain the peace. Furthermore, the empire's legal and judicial system guaranteed the rights not only of territorial rulers and urban magistrates but also of the inhabitants of territories and cities against their rulers. The empire saw the development of a legal culture that had no parallel in Europe and the 'juridifcation' of social and political conflict marked the German territories out from neighbouring countries.

Since the 1970s research on the Holy Roman Empire has proliferated in almost every direction. Key institutions, such as the Reichstag, the Reichskammergericht, the Reichshofrat and the Kreise, have been the subject of major research projects. Since the early 1990s the non-national or pre-national character of the empire has been challenged by scholars such as Georg Schmidt and Johannes Burkhardt, generating often heated controversies which have attracted the attention of doctoral students and stimulated further work. ${ }^{17}$ Equally stimulating have been the debates provoked by Schmidt's work on the concept of 'German liberty', which has suggested lines of continuity to the modern era which no longer rely on any kind of Sonderweg. The next logical step would be to challenge the still prevalent view that the empire had to fail in 1806. Without Napoleon's decisive intervention it might well have adapted and survived.

Most recently a new cultural approach to the history of the old empire, building on the work of medievalists such as Gerd Althoff, has explored early modern modes of symbolic communication. Often in opposition to those who emphasise the new structures developed in the empire from 1495, the approach emphasises that the empire was first and foremost a feudal structure, held together not by a legal framework or a constitution but rather by the

\footnotetext{
${ }^{16}$ Repgen died in April 2017; his key work, first published in 1957, was: Dreißigjähriger Krieg und Westfälischer Friede. Studien und Quellen, revised and extended edn ed. Franz Bosbach and Christoph Kampmann (Paderborn, 2015). On Lutz and Aretin see: Karl Otmar von Aretin, 'Heinrich Lutz', Historische Zeitschrift, 244 (1987), pp. 487-93; Heinz Duchhardt, 'Nekrolog Karl Otmar Freiherr von Aretin (1923-2014)', Historische Zeitschrift, 299 (2014), pp. 285-90.

${ }^{17}$ Joachim Whaley, 'The Old Reich in Modern Memory: Recent Controversies Concerning the "Relevance" of Early Modern German History', in David Midgley and Christian Emden (eds), German History, Literature and the Nation (Selected Papers from the Conference The Fragile Tradition Cambridge 2002, vol. 2 (Oxford, 2004), pp. 25-49; Peter H. Wilson, 'Still a monstrosity? Some Reflections on Early Modern German Statehood, The Historical Journal, 49 (2006), pp. 565-76.
} 
performance of the bonds of loyalty formed between the emperor and the individual estates. ${ }^{18}$ André Krischer has even gone so far as to suggest that the empire was essentially fictive in nature, existing only in the discourse of symbolic communication and the imagined realm of performance. $^{19}$

At every stage of this remarkable historiographical revolution developments in German historiography have stimulated work in the English-speaking world. Tim Blanning's study of Mainz in the eighteenth century was a pioneering work in English when it appeared in 1974 but it also reflected his encounter with Karl Otmar von Aretin at the Institut fur Europäische Geschichte Mainz. ${ }^{20}$ Many other academic biographies would reveal similar encounters. The dramatic increase in the amount of work on the Holy Roman Empire in German is more than matched in the UK and North America. The publication since 2012 of three major works on the empire by UK historians underlines the significance of the Holy Roman Empire as a topic of research in the English-speaking world. ${ }^{21}$

Rarely explicitly acknowledged, Central European History, especially in its review articles, has made an indispensable contribution to this research over half a century. It is fitting that we should celebrate the first fifty years and hope for many more to come.

\section{GONVILLE \& CAIUS COLLEGE, CAMBRIDGE}

\footnotetext{
${ }^{18}$ Barbara Stollberg-Rilinger, Des Kaisers alte Kleider. Verfassungsgeschichte und Symbolsprache des Alten Reiches (Munich, 2008) - English translation: The Emperor's Old Clothes: Constitutional History and the Symbolic Language of the Holy Roman Empire (London, 2015).

${ }^{19}$ Andre Krischer, 'Conclusion: New Directions in the Study of the Holy Roman Empire - A Cultural Approach', in Coy et al. (eds) The Holy Roman Empire, pp. 265-70, at p. 267.

20 T.C.W. Blanning, Reform and Revolution in Mainz, 1743-1803 (Cambridge, 1974).

${ }^{21}$ Len Scales, The Shaping of German Identity: Authority and Crisis, 1245-1414 (Cambridge 2012); Joachim Whaley, Germany and the Holy Roman Empire, 1493-1806, 2 vols (Oxford 2012); Peter H. Wilson, The Holy Roman Empire: A Thousand Years of Europe's History (London, 2016).
} 